\title{
Perceptions of animal experimentation: a longitudinal survey with veterinary students in Araçatuba, São Paulo, Brazil
}

Gisele F. Machado, Guilherme D. Melo, Silvia H. V. Perri, Fernando V. Fernandes, Olívia C. Moraes, Milena S. Souza, Fernanda G. Grano, José E. S. Silva \& Cáris M. Nunes

To cite this article: Gisele F. Machado, Guilherme D. Melo, Silvia H. V. Perri, Fernando V. Fernandes, Olívia C. Moraes, Milena S. Souza, Fernanda G. Grano, José E. S. Silva \& Cáris M. Nunes (2017) Perceptions of animal experimentation: a longitudinal survey with veterinary students in Araçatuba, São Paulo, Brazil, Journal of Biological Education, 51:4, 391-398, DOI: 10.1080/00219266.2016.1257501

To link to this article: https://doi.org/10.1080/00219266.2016.1257501

曲 Published online: 21 Nov 2016.

Submit your article to this journal $₫$

山 Article views: 359

View Crossmark data $\subset$ 


\title{
Perceptions of animal experimentation: a longitudinal survey with veterinary students in Araçatuba, São Paulo, Brazil
}

\author{
Gisele F. Machado a, Guilherme D. Melo ${ }^{a \S}$ (D), Silvia H. V. Perrib ${ }^{b}$ Fernando V. Fernandesa, \\ Olívia C. Moraes ${ }^{a}$, Milena S. Souza ${ }^{a}$, Fernanda G. Grano ${ }^{a}$, José E. S. Silva ${ }^{a}$ and Cáris M. Nunes ${ }^{b}$ \\ ${ }^{a}$ Department of Animal Clinics, Surgery and Reproduction, College of Veterinary Medicine, UNESP - Univ Estadual \\ Paulista, Araçatuba, Brazil; 'bepartment of Production and Animal Health; College of Veterinary Medicine; UNESP - \\ Univ Estadual Paulista, Araçatuba, Brazil
}

\begin{abstract}
Animal experimentation is a controversial topic, especially among the general public and the scientific community. Thirty-eight undergraduate students attending the College of Veterinary Medicine - São Paulo State University in the municipality of Araçatuba, São Paulo, Brazil, were followed up between 2008 and 2011 and were asked to complete an annual questionnaire focused on different aspects of animal experimentation, including the animal species involved, the objectives of the research, ethics, animal welfare and euthanasia. Most students agreed that animal testing is not morally incorrect, and the dynamics of students' attitudes were notable: undergraduates tended to change their opinion over time, with junior students opposing animal experimentation more than seniors do, indicating that the more scientific knowledge the students acquire, the more favourable to animal experimentation they become. Nevertheless, they agreed that research must consider the basic principles of animal welfare.
\end{abstract}

\section{KEYWORDS}

Animal welfare; euthanasia; laboratory animals; questionnaires; veterinary education

\section{Introduction}

Traditionally, the undergraduate veterinary medicine curriculum focuses on the treatment of diseases and the relief of animal suffering (Broom 2005). However, with growing global concern for animal welfare and the reduction of animal use in substance testing and experiments, animal welfare and ethics in animal experimentation have become standard components of the veterinary medicine curriculum (Herzog 2002; Russow 2002; Lord et al. 2010).

Philosophical interest in animal ethics began at Oxford University in the 1960s, when a group of students read the book Animal Machine by Harrison (1964) and became vegetarians (Thompson 2010). This subject was further addressed by one of those students in the book Animal Liberation (Singer 1975), which emphasised the animals' suffering. The use of animals in universities, teaching and research must be governed by humanitarian principles of animal experimentation, as determined by Russell and Burch (1959), who recommend the use of the 3Rs: replacement (the use of alternative methods when possible), reduction (an experimental design that minimises the number of animals required) and refinement (the improvement of techniques). 
Although many researchers support the use of animals in scientific experiments, this subject remains controversial, especially among the general public and the scientific community (Rowan, Loew, and Weer 1995; Croce 2000; Newkirk 2000). In the year of 2005, Taylor et al. (2008) estimated that 1,169,517 animals were used in Brazilian experiments, based on the amount of papers published in 2006, but official data are missing. In Brazil, the federal law \#9605/98 (Brasil 1998) penalises the use of animals in experiments if animals experience pain and alternative methods are available. In the year of 2008, the federal law \#11794/08 (Brasil 2008) established more restrictive procedures for the scientific use of animals, specifically from the subphylum Vertebrata, including the mandatory approval by an ethics committee in animal experimentation, the prohibition of experiments causing pain or distress, the reduction of the number of animals and the diminution of unnecessary repetitions of tests. This has reopened discussions of standardisation and the ethical use of animals for research.

Some studies focused on people's attitudes and empathy towards animals (Paul and Podberscek 2000) and their attitudes towards the welfare of livestock (Levine, Mills, and Houpt 2005). In addition, surveys have been conducted to determine the attitudes of groups of people who directly interact with animals compared with people who do not (Plous 1998; Goldsmith, Clark, and Lafferty 2006). However, few studies investigate the opinions of veterinary medicine undergraduate students on these topics (Heleski, Mertig, and Zanella 2004; Serpell 2005; Heleski and Zanella 2006), and limited data are available concerning veterinarians' attitudes towards animal experimentation (Hagelin, Carlsson, and Hau 2003; Diniz et al. 2006). It is important to know the attitudes of students towards animal experimentations to promote a better balance between the antagonism of veterinary science: the care provided to animals versus the use of animals in research and training.

In Brazil, the veterinary curriculum is divided into two main groups: the first academic years include basic subjects such as chemistry, anatomy, physiology, immunology, pharmacology, statistics, humanities and social sciences, whereas the last years include the professionalising courses such as small and large animal clinics and surgery, theriogenology, diagnostic pathology, preventive veterinary medicine and public health, animal production (Brasil 2003). Since the veterinary medicine curriculum directly involves the handling, the management, and occasionally the euthanasia of animals in practical lessons and since students may also participate in research projects based on animal models, we aimed to determine the attitudes of veterinary medicine undergraduate students regarding the use of animals in experiments and practical lessons and whether these opinions changed as the students progressed through the course.

\section{Materials and methods}

The survey was developed at the College of Veterinary Medicine - São Paulo State University (UNESP) in the municipality of Araçatuba, São Paulo State, Brazil (latitude $21^{\circ} 2^{\prime} 3^{\prime \prime}$ S; longitude $50^{\circ} 5^{\prime} 58^{\prime \prime} \mathrm{W}$ ). During the period of the study, according to the National Examination of Students' Performance accomplished in the years of 2007, 2010 and 2013 (Enade 2016), this is a five-star college and rated the second best Veterinary Medicine College in Brazil, among 160 total colleges.

Thirty-eight undergraduate students, 25 female and 13 male, enrolled in the veterinary medicine course participated voluntarily in this survey. These students were enrolled in the first academic year in 2008 (average age: 18.9 years) were evaluated separately, comparatively and continuously through the years, until they reached the fourth academic year in 2011 (totalling 152 questionnaires). Annually, 45 students are admitted to this veterinary school, in a five-year academic programme, and 38 of them could be followed up during four years.

The questionnaire consisted of 23 items based mostly on Swami and colleagues' (2008) survey, regarding animal experimentation, animal welfare and euthanasia (Table 1). The questionnaire was composed of three sets of questions, (1) investigating students' attitudes towards the species involved in the experimentation, (2) to solicit opinions with respect to the different objectives of animal experimentation, and (3) with questions related to ethics, animal welfare and euthanasia. 
Table 1. Students' feelings towards animal experimentation, animal welfare and euthanasia.

\begin{tabular}{|c|c|c|c|c|c|c|}
\hline & \multirow[b]{2}{*}{ Questions $^{1}$} & \multicolumn{4}{|c|}{$\begin{array}{c}\text { Positive answers / Academic } \\
\text { year }(\%)^{2}\end{array}$} & \multirow[b]{2}{*}{$P$} \\
\hline & & 1 & 2 & 3 & 4 & \\
\hline 1 & $\begin{array}{l}\text { Under certain circumstances, experiments involving insects are } \\
\text { justifiable. }\end{array}$ & 78.6 & 86.5 & 88.4 & 92.9 & 0.0824 \\
\hline 2 & $\begin{array}{l}\text { Under certain circumstances, experiments involving birds are justifi- } \\
\text { able. }\end{array}$ & 52.4 & 70.3 & 81.4 & 85.7 & $0.0007^{*}$ \\
\hline 3 & $\begin{array}{l}\text { Under certain circumstances, experiments involving rodents (e.g., rats } \\
\text { and mice) are justifiable. }\end{array}$ & 81.0 & 89.2 & 90.7 & 100.0 & $0.0137^{*}$ \\
\hline 4 & $\begin{array}{l}\text { Under certain circumstances, experiments involving cats are justifia- } \\
\text { ble. }\end{array}$ & 50.0 & 70.3 & 83.7 & 85.7 & $0.0002^{*}$ \\
\hline 5 & $\begin{array}{l}\text { Under certain circumstances, experiments involving dogs are justifi- } \\
\text { able. }\end{array}$ & 52.4 & 67.6 & 83.7 & 85.7 & $0.0004^{*}$ \\
\hline 6 & $\begin{array}{l}\text { Under certain circumstances, experiments involving primates (e.g., } \\
\text { monkeys, apes) are justifiable. }\end{array}$ & 53.7 & 67.6 & 86.0 & 85.2 & $0.0005^{*}$ \\
\hline 7 & $\begin{array}{l}\text { I approve of animal experimentation that leads to the development of } \\
\text { effective treatments for physical diseases afflicting humans. }\end{array}$ & 66.7 & 67.6 & 81.4 & 77.8 & 0.1323 \\
\hline 8 & $\begin{array}{l}\text { I approve of animal experimentation that leads to the development of } \\
\text { effective treatments for physical diseases afflicting animals. }\end{array}$ & 83.3 & 83.8 & 95.3 & 89.3 & 0.1747 \\
\hline 9 & $\begin{array}{l}\text { I approve of animal experimentation that leads to the development of } \\
\text { effective treatments for mental diseases afflicting humans. }\end{array}$ & 42.9 & 59.5 & 72.1 & 66.7 & $0.0122^{*}$ \\
\hline 10 & $\begin{array}{l}\text { I approve of animal experimentation that contributes to the education } \\
\text { and training of people. }\end{array}$ & 21.4 & 27.0 & 48.8 & 39.3 & $0.0210^{*}$ \\
\hline 11 & $\begin{array}{l}\text { I approve of animal experimentation that reveals basic facts about } \\
\text { biological processes (e.g., respiration, digestion). }\end{array}$ & 9.5 & 24.3 & 28.6 & 14.3 & 0.3301 \\
\hline 12 & $\begin{array}{l}\text { I approve of animal experimentation that reveals basic facts about } \\
\text { psychological processes (e.g., learning, thinking). }\end{array}$ & 21.4 & 37.8 & 58.1 & 35.7 & $0.0304^{*}$ \\
\hline 13 & $\begin{array}{l}\text { I approve of animal experiments that help to ensure that food is safe } \\
\text { for people to eat. }\end{array}$ & 19.0 & 27.0 & 44.2 & 51.9 & $0.0012^{*}$ \\
\hline 14 & $\begin{array}{l}\text { I approve of animal experimentation that helps to ensure that house- } \\
\text { hold cleaners are safe for people to use. }\end{array}$ & 2.4 & 5.4 & 4.7 & 7.1 & 0.4021 \\
\hline 15 & $\begin{array}{l}\text { I approve of animal experimentation that helps to ensure that cosmet- } \\
\text { ics are safe for people to use. }\end{array}$ & 4.8 & 0.0 & 9.3 & 10.7 & 0.1453 \\
\hline 16 & All animal experimentation is morally incorrect. & 34.1 & 29.7 & 11.6 & 14.3 & $0.0100^{*}$ \\
\hline 17 & Some experiments cannot be performed without animals. & 62.5 & 73.0 & 79.1 & 82.1 & $0.0453^{*}$ \\
\hline 18 & $\begin{array}{l}\text { Every animal that is used in an experiment suffers in one way or } \\
\text { another. }\end{array}$ & 81.0 & 75.7 & 86.0 & 81.5 & 0.6491 \\
\hline 19 & $\begin{array}{l}\text { Painful experiments on animals should not be prevented because } \\
\text { they can provide knowledge about and relief from human suffering. }\end{array}$ & 2.4 & 5.4 & 14.6 & 14.3 & $0.0289^{*}$ \\
\hline 20 & It is wrong to kill animals, even if the method is painless. & 15.0 & 8.1 & 7.0 & 0.0 & $0.0294^{*}$ \\
\hline 21 & $\begin{array}{l}\text { Stray animals that must be euthanised should be used in experiments } \\
\text { that could provide valuable information. }\end{array}$ & 57.1 & 64.9 & 76.7 & 60.7 & 0.3607 \\
\hline 22 & $\begin{array}{l}\text { I agree and I would indicate the euthanasia of animals that show to be } \\
\text { suffering, even under treatment. }\end{array}$ & 75.0 & 80.6 & 92.7 & 100.0 & $0.0010^{*}$ \\
\hline 23 & Like humans, animals have souls. & 85.7 & 94.6 & 97.6 & 92.6 & 0.1453 \\
\hline
\end{tabular}

${ }^{a}$ questions extracted from Swami, Furnham, and Christopher (2008)

${ }^{b} n=38 /$ year

*indicates statistical significance $(p<0.05)$.

The answer choices were 'yes' and 'no'; the binary format was chosen instead of the Likert format to avoid neutrality in the answers (Dolnicar, Grün, and Leisch 2011). The questionnaire was distributed annually from 2008 to 2011 and, when possible, simultaneously to all students, i.e. typically at the end of lectures. The participants were requested to be honest in their responses and to answer the questionnaire individually and anonymously. No distinction was made regarding age, sex, and political, religious, or economic backgrounds.

The frequencies of the answers were expressed as percentages, and they were analysed over time using the Chi-square test for trends. Statistical significance was accepted when $p<0.05$. All statistical analyses were performed using Prism 6 (Prism v6.02, GraphPad). This survey was approved by the institutional ethics committee (UNESP, process \#2008-01846). 


\section{Results}

Students were asked several questions about their attitudes towards animal experimentation, with the first set of questions investigating attitudes towards the species involved in the experimentation (Table 1).

Despite the academic year, there were noticed two patterns of answers, a more positive feeling towards experiments involving insects and rodents, and a less positive feeling when the experimental species are birds, cats, dogs or primates. These patterns of attitudes were similar over time, with an increase in every academic year, with senior-level students being more favourable to animal experimentation than junior-level students (Figure 1).

The second set of questions aimed to solicit opinions with respect to the different objectives of animal experimentation. Most students approved using animals in researches that would help develop effective treatments for physical diseases afflicting both humans and animals. The approval rate decreased drastically when the research aim involved cosmetics, household products or biological processes. Students expressed mixed feelings regarding studies on therapy for human mental disorders, training people, studying psychological processes and food safety (Figure 1). Over time, attitudes regarding research on disease therapies were similar to those regarding the use of animals

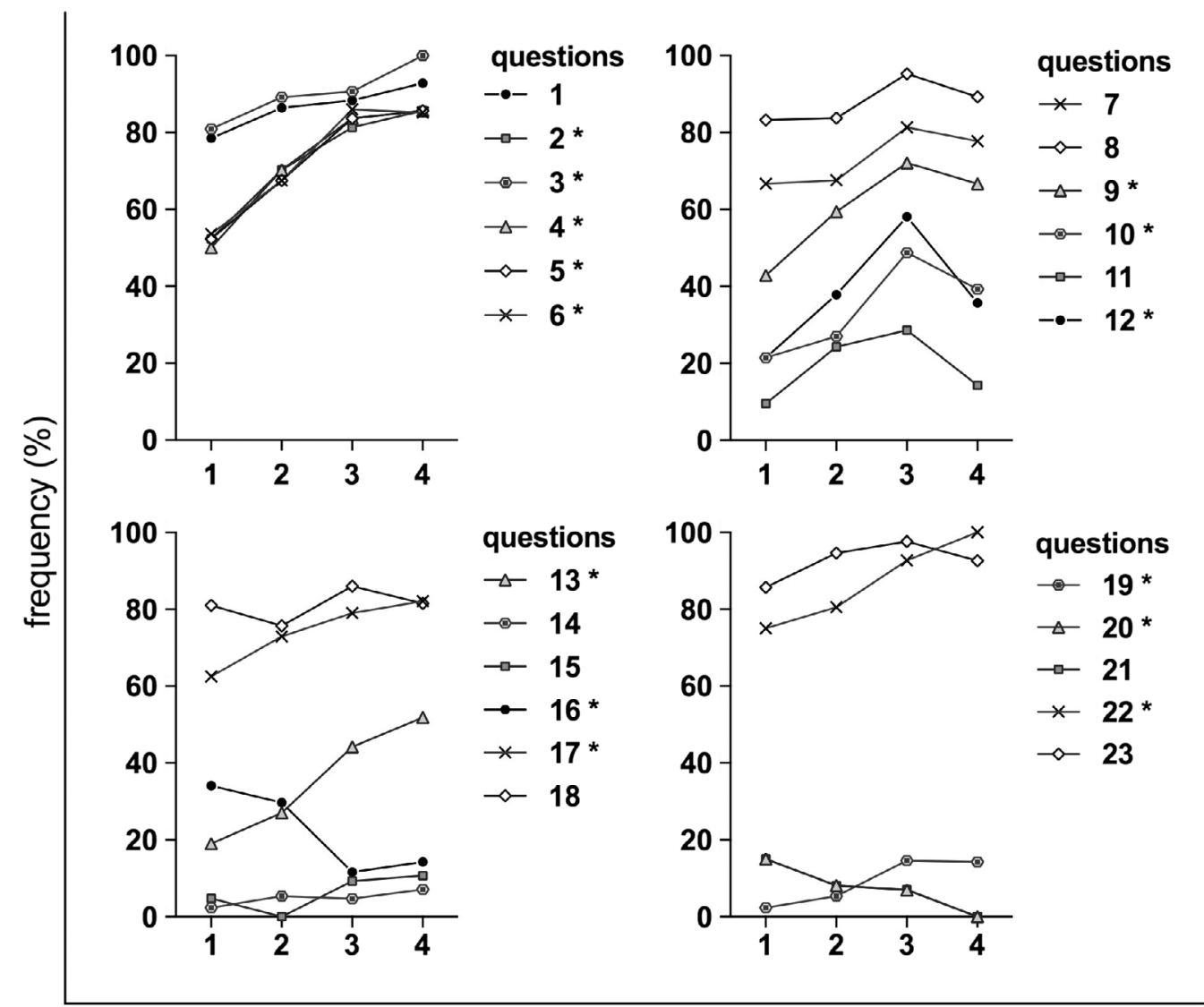

academic year

Figure 1. Dynamics of veterinary medicine students' attitudes towards animal experimentation, animal welfare and euthanasia. Note: Lines represent the positive answers. Questions numbers followed by * indicate significant changes over time $(p<0.05)$. The answers were taken from the same undergraduate students $(n=38)$, starting at the first academic year (2008) until the fourth academic year (2011). Refer to Table 1 for questions numbering. 
in research. A notable pattern of opinions was observed concerning the use of animals for training people, with the approval rate increasing from $21.4 \%$ in the first academic year to $39.3 \%$ in the fourth academic year. An identical distribution was observed in studies of psychological processes (learning and thinking), with the acceptance rate being the lowest in the first academic year (21.4\%) and peaking in the third year $(58.1 \%)$. For this set of questions, except for question 13 (concerning food safety), the positive answers from the students of the fourth academic year were slightly inferior to the students of the third academic year.

The third set of questions was related to ethics, animal welfare and euthanasia. In general, the students did not find that animal experimentation is morally incorrect, and this positive feeling increased over time, along with the idea that the use of animals is essential to some types of experiments (Figure 1). The students believe that every animal presents a kind of sufferance during experiments and they were completely against painful experiments; the average approval rate was low but increased over time.

Furthermore, students generally agreed to the use of stray animals that would be otherwise euthanised (Figure 1). The greater part of the students believed that euthanasia should be indicated for animals that are deemed to be suffering. The acceptance rate for these questions significantly increased over time, reaching $100 \%$ in the fourth academic year. Finally, when asked if they believed that the animals have souls, the vast majority of the students answered yes, throughout the four academic years.

\section{Discussion}

Currently in Brazil there is a growing concern regarding the use of animals in experiments, and several authors have been discussing this topic, especially in the view of the Brazilian federal law \#11794/08 (d'Acampora et al. 2009; Marques, Morales, and Petroianu 2009; Tréz 2010; Filipecki et al. 2011). However, studies reporting people's feelings towards this subject are lacking. The present study aimed to understand the attitudes of veterinary medicine undergraduate students towards the use of animals in experiments and practical lessons and to determine if opinions changed throughout the course.

The surveyed undergraduate student body was composed of a noticeably higher number of female students (66\%), thus corroborating other studies that report an increase in the number of women enrolled in veterinary and animal science courses (Britt et al. 2008; Chubin and Mohamed 2009). The predominance of women in these fields of study may be related to the overall increase in the number of students willing to work with companion animals and in students' increased feelings of empathy towards animals (Hazel et al. 2011). Besides the complex relationship between empathy and morality, the students did not find animal experimentation morally incorrect, and agreed that some experiments still need the use of animals. Corroborating our data, in a survey of the only veterinary school in Sweden, the vast majority of the students found animal experimentation morally acceptable (Hagelin, Hau, and Carlsson 2000). Further, in our survey, the higher acceptance rate of animal experimentation was observed in the last two academic years, validating the premise that the more scientific knowledge the students acquire, the more favourable to animal experimentation they become.

Whereas some authors defend the hypothesis that the level of education is correlated with a more negative attitude towards the use of animals in research (Furnhan and Pinder 1990), others agree that the acceptance rate of animal experimentation increases with the accumulation of objective information on the topic (Culliton 1991). In general, in our survey, senior-level students (third and fourth academic years) tended to favour animal experimentation, compared to junior-level students (first and second academic years), in a similar way as observed by Hagelin, Hau, and Carlsson (1999) and Vigorito (1996). Undergraduate students in England were more opposed to animal experimentation than those in America (Furnhan and Pinder 1990). Besides the geographical factor, the academic programme seems also to influence students' opinion: engineering, law and medical students were more supportive of animal use in biomedical research than pre-school-teaching students (Hagelin, Hau, and Carlsson 1999).

There was detected a remarkable change in the students' opinion over time when the focus of the questions was the animal species involved in experimentation. Hazel et al. (2011) detected that 
veterinary and animal-science students' attitudes changed according to the species, revealing that students felt more empathy towards companion animals than livestock. Consistent with those authors, the students in our survey felt more comfortable using rodents and insects in experiments rather than companion animals and primates, possibly because of the close bond between humans and companion animals (no difference between dogs and cats), and humans' evolutionary proximity to monkeys and apes. However, throughout the time, the acceptance rate of using these animals in experimentation increased about $30 \%$.

Additionally, students' attitudes are influenced by the context of the research (Knight et al. 2009). In the present survey, there was a massive rejection of the animal using in researches involving cosmetics and household cleaners, most likely because students believed these topics are less essential and it is not worth the suffering that the animals must endure, especially because they are aware of the possible availability of alternative to animal experimentation in these fields (Ponec 2002; Pfuhler et al., 2010). On the other hand, the students were highly supportive of the use of animals to develop treatments for human and animal diseases.

The veterinary curriculum seems to influence the opinions of the students. There was mixed feeling concerning the use of animals in education/training and to the study of basic biological/psychological processes; in general, the acceptance rate increased over the first three academic years, possibly because the students felt the need to use animals to better understand and learn theoretical subjects; and then a slight decrease was observed in the fourth academic year, maybe due to the fact that during the fourth academic year, the students perform practical rotations in hospital disciplines, dealing with 'patients' and not 'laboratory animals'. Further, an elective course of Animal Behavior and Animal Welfare is available for fourth-year students, which might influence their opinions as well. Mixed-feeling was also expressed by Medical students regarding these topics: $50 \%$ of the students expressed negative feelings towards the use of animals in practical lessons, $17.8 \%$ expressed positive feelings, $27.3 \%$ expressed curiosity and 4.9\% expressed indifference (Diniz et al. 2006).

Some experiments could not be performed without animals, agreed the students, however they also agreed that these animals suffer in one way or another, and they completely rejected animal experimentation involving pain. Accordingly, American psychology students tended to approve animal studies involving observation or confinement, but they did not support studies involving pain or death (Plous 1996).

Regarding euthanasia, it is a common practice present in the veterinarians' professional life. The greater part of the students felt that is not wrong to kill animals, and the acceptance rate to euthanasia increased over time, with all the fourth-year students favourable to it. This same scenario was observed when the euthanasia could release the animals from suffering. Accordingly, Manzano et al. (2007) verified the opinions of veterinary medicine students about euthanasia after witnessing the euthanasia of a jaguar (Panthera onca) in a Brazilian zoo: $71 \%$ of the students were favourable to euthanasia when it focused on the release of suffering, however, $54 \%$ approved euthanasia for public health reasons and only $38 \%$ approved euthanasia as a measure of population control. Further, the students in our survey felt comfortable to include in experiments the animals that were already destined to be euthanised. Nevertheless, the vast majority of the students believe that animals have a soul. Despite the fact that the religious background of the students was not evaluated, this scenario could also be due to the concept of animals as sentient beings and also to the concept of humanisation of animals, specially because of the strong emotional bond between people and their companion animals.

These results show that opinions towards animal experimentation change according to the aim of the research and to the academic year, with senior students being more supportive towards animal experimentation, however, this effect may also be related to increasing age and general maturation in addition to their veterinary studies. Even if 38 students seem to be a small sample, they represent $84.4 \%(38 / 45)$ of the annual number of entering students. Although most students believed that animal experimentation is important and must continue, they agree that research must not cause animal suffering and must consider the basic principles of animal welfare. Studies such as this one provide interesting data regarding the feelings of veterinary medicine students, who are going to directly 
interact with animals in a near future, and it is of importance for professors and researchers who will need to adapt their learning methods to this specific public face to the actual concepts in animal experimentation and animal welfare.

\section{Acknowledgments}

We would like to thank all of the undergraduate students who took time to answer the questionnaire.

\section{ORCID}

Guilherme D. Melo (D) http://orcid.org/0000-0003-0747-7760

\section{References}

Brasil. 1998. Lei $n^{\circ} 9.605$ de 12 de fevereiro de 1998. Dispõe sobre as sanções penais e administrativas derivadas de condutas e atividades lesivas ao meio ambiente, e dá outras providências. Brasília: Diário Oficial da União, 13 de fevereiro de 1998; Seção 1, 31:1-5. [Law No. 9,605 of February 12, 1998. Provides for Criminal and Administrative Sanctions Derived from Harmful Conducts and Activities to the Environment, and Other Measures. Brasília: Official Union Journal, February 13, 1998; Section 1, 31:1-5].

Brasil. 2003. Ministério da Educação. Conselho Nacional de Educação Câmara de Educação Superior. Resolução CNE/CES 1, de 18 de fevereiro de 2003 [Ministry of Education. National Council of Education. Higher Education Chamber. Resolution CNE / CES 1, of February 18, 2003]. Institui Diretrizes Curriculares Nacionais dos Cursos de Graduação em Medicina Veterinária. Brasília : Diario Oficial Uniao, 20 de fevereiro de 2003; Seção1:22 [Establishes National Curricular Guidelines for Veterinary Medicine Undergraduate Courses. Brasília: Official Union Journal, February 20, 2003; Section 1:22].

Brasil. 2008. Lei $n^{\circ} 11.794$ de 8 de outubro de 2008. Regulamenta o inciso VII do $\$ 1^{\circ}$ do art.225 da Constituição Federal, estabelecendo procedimentos para o uso científico de animais; revoga a Lei no 6.638, de 8 de maio de 1979; e dá outras providências. Brasília: Diário Oficial da União, 9 de outubro de 2008; Seção 1, 196:1-2. [14 Law No. 11,794 of October 8, 2008. Regulates paragraph VII of $\$ 1$ of art.225 of the Federal Constitution, establishing procedures for the scientific use of animals; Revokes Law No. 6,638, of May 8, 1979; And makes other arrangements. Brasília: Official Union Journal, October 9, 2008; Section 1, 196: 1-2].

Britt, J. H., E. D. Aberle, K. L. Esbenshade, and J. R. Males. 2008. "Animal Science Departments of the Future." Journal of Animal Science 86: 3235-3244.

Broom, D. M. 2005. “Animal Welfare Education: Development and Prospects." Journal of Veterinary Medical Education 32: $438-441$.

Chubin, D. E., and S. Mohamed. 2009. "Increasing Minorities in Veterinary Medicine: National Trends in Science Degrees, Local Programs, and Strategies." Journal of Veterinary Medical Education 36: 363-369.

Croce, P. 2000. Vivisection or Science? An Investigation into Testing Drugs and Safeguarding Health New York: Zed Books.

Culliton, B. J. 1991. “Can Reason Defeat Unreason?” Nature 351: 517.

D’Acampora, A. J., L. F. Rossi, J. B. Ely, and Z. A. Vasconcellos. 2009. “Is Animal Experimentation Fundamental?” Acta Cirurgica Brasileira 24: 423-425.

Diniz, R., A. L. A. Duarte, C. A. S. Oliveira, and M. Romiti. 2006. “Animais em aulas praticas, podemos substituí-los com a mesma qualidade de ensino? [Animals in Practical Classes, Can we Replace them with the Same Quality of Teaching?]." Revista Brasileira de Educação Médica [Brazilian Journal of Medical Education] 30: 31-40.

Dolnicar, S., B. Grün, and F. Leisch. 2011. “Quick, Simple and Reliable: Forced Binary Survey Questions.” International Journal of Market Research 53: 231-252.

Enade. 2016. Exame Nacional de Desempenho de Estudantes. Accessed June 15. http://portal.inep.gov.br/enade

Filipecki, A. T., C. J. Machado, S. Valle, and M. O. Teixeira. 2011. "The Brazilian Legal Framework on the Scientific Use of Animals." ILAR Journal 52: E8-E15.

Furnhan, A., and A. Pinder. 1990. "Young People's Attitudes to Experimentation on Animals." Psychologist 10: 444-448.

Goldsmith, R. E., R. A. Clark, and B. Lafferty. 2006. "Intention to Oppose Animal Research: The Role of Individual Differences in Nonconformity." Social Behavior and Personality: An International Journal 34: 955-964.

Hagelin, J., H. E. Carlsson, and J. Hau. 2003. "An Overview of Surveys on How People View Animal Experimentation: Some Factors That May Influence the Outcome." Public Understanding of Science 12: 67-81.

Hagelin, J., J. Hau, and H. E. Carlsson. 1999. "Undergraduate University Students' Views of the Use of Animals in Biomedical Research.” Academic Medicine 74: 1135-1137.

Hagelin, J., J. Hau, and H. E. Carlsson. 2000. "Attitude of Swedish Veterinary and Medical Students to Animal Experimentation." Veterinary Record 146: 757-760. 
Harrison, R. 1964. Animal Machines, the New Factory Farming Industry London: Vincent Stuart Publishers.

Hazel, S. J., T. D. Signal, and N. Taylor. 2001. "Can Teaching Veterinary and Animal-science Students about Animal Welfare Affect Their Attitude Toward Animals and Human-related Empathy." Journal of Veterinary Medical Education 38: 74-83.

Heleski, C. R., A. G. Mertig, and A. J. Zanella. 2004. "Assessing Attitudes toward Farm Animal Welfare: A National Survey of Animal Science Faculty Members." Journal of Animal Science 82: 2806-2814.

Heleski, C. R., and A. J. Zanella. 2006. "Animal Science Student Attitudes to Farm Animal Welfare." Anthrozoos: A Multidisciplinary Journal of the Interactions of People \& Animals 19: 3-16.

Herzog, H. 2002. "Ethical Aspects of Relationships Between Humans and Research Animals." ILAR Journal 43: $27-32$.

Knight, S., A. Vrij, K. Bard, and D. Brandon. 2009. "Science Versus Human Welfare? Understanding Attitudes Toward Animal Use." Journal of Social Issues 65: 463-483.

Levine, E. D., D. S. Mills, and K. A. Houpt. 2005. "Attitudes of Veterinary Students at One US College toward Factors Relating to Farm Animal Welfare." Journal of Veterinary Medical Education 32: 481-490.

Lord, L. K., J. B. Walker, C. C. Croney, and G. C. Golab. 2010. "A Comparison of Veterinary Students Enrolled and Not Enrolled in an Animal-Welfare Course." Journal of Veterinary Medical Education 37: 40-48.

Manzano, M. A., J. R. Pachaly, K. H. Majczak, A. V. Silva, and E. M. G. Ciffoni. 2007. "Euthanasia Under the Perspective of Veterinary Medicine and Biological Sciences Students." Revista Brasileira De Ciência Veterinária 14: 155-158.

Marques, R. G., M. M. Morales, and A. Petroianu. 2009. "Brazilian Law for Scientific Use of Animals." Acta Cirurgica Brasileira 24: 69-74.

Newkirk, L. 2000. Free the Animals, the Story of the Animal Liberation Front Los Angeles, CA: Lantern Books.

Paul, E., and A. Podberscek. 2000. "Veterinary Education and Students Attitudes towards Animal Welfare." Veterinary Record 146: 269-272.

Pfuhler, S., A. Kirst, M. Aardema, N. Banduhn, C. Goebel, D. Araki, M. Costabel-Farkas, et al. 2010. "A Tiered Approach to the Use of Alternatives to Animal Testing for the Safety Assessment of Cosmetics: Genotoxicity. A COLIPA Analysis.” Regulatory Toxicology and Pharmacology 57 (2-3): 315-324. doi:10.1016/j.yrtph.2010.03.012.

Plous, S. 1996. "Attitudes Toward the Use of Animals in Psychological Research and Education." American Psychologist 51: 1169-1180.

Plous, S. 1998. "Signs of Change Within the Animal Rights Movement: Results from a Follow-up Survey of Activists." Journal of Comparative Psychology 112: 48-54.

Ponec, M. 2002. “Skin Constructs for Replacement of Skin Tissues for in Vitro Testing." Advanced Drug Delivery Reviews 54: S19-S30.

Rowan A. N., F. M. Loew, J. C. Weer. 1995. The Animal Research Controversy: Protest, Process \& Public Policy: An Analysis of Strategic Issues North Grafton, MA: Center for Animals \& Public Policy, Tufts University School of Veterinary Medicine.

Russell, W. M. S., and R. L. Burch. 1959. The Principles of Humane Experimental Technique London: Meuthen.

Russow, L. M. 2002. "Ethical Implications of the Human-Animal Bond in the Laboratory." ILAR Journal 43: 33-37.

Serpell, J. A. 2005. "Factors Influencing Veterinary Students' Career Choices and Attitudes to Animals." Journal of Veterinary Medical Education 32: 491-496.

Singer, P. 1975. Animal Liberation New York: Avon Books.

Swami, V., A. Furnham, and A. N. Christopher. 2008. "Free the Animals? Investigating Attitudes toward Animal Testing in Britain and the United States." Scandinavian Journal of Psychology 49: 269-276.

Taylor, K., N. Gordon, G. Langley, and W. Higgins. 2008. "Estimates for Worldwide Laboratory Animal Use in 2005." Alternative to Laboratory Animals 36: 327-342.

Thompson, P. B. 2010. "Animal Ethics and Public Expectations: The North American Outlook." Journal of Veterinary Medical Education 37: 13-21.

Tréz, T. A. 2010. "Refining Animal Experiments: The First Brazilian Regulation on Animal Experimentation." Alternative to Laboratory Animals 38: 239-244.

Vigorito, M. 1996. “An Animal Rights Attitudes Survey of Undergraduate Psychology Students." Psychological Reports 79: 131-142. 